\title{
Monoclonal Antibodies to Gonococcal Outer Membrane Protein IB: Use in Investigation of the Potential Protective Effect of Antibodies Directed against Conserved and Type-specific Epitopes
}

\author{
By M. VIRJI,* K. ZAK AND J. E. HECKELS \\ Department of Microbiology, University of Southampton Medical School, \\ Southampton General Hospital, Southampton SO9 4XY, UK
}

(Received 13 November 1985)

\begin{abstract}
Several monoclonal antibodies directed against gonococcal outer membrane protein IB have been used in in vitro assays to investigate their potential efficacy in protection against gonococcal infection. In a cytotoxicity assay, virulence of the variant P9-17 for epithelial cells in tissue culture was reduced in the presence of three of the four antibodies which recognized typespecific epitopes. Similarly, virulence of $\mathrm{P} 9-17$ as well as a recent isolate was reduced in the presence of the one antibody, SM24, which reacted with a conserved epitope. This antibody was also bactericidal in the presence of complement, and in addition was opsonic for several protein IB-expressing strains as determined by polymorphonuclear leucocyte chemiluminescence measurements. Similarly, all the type-specific antibodies were opsonic for P9 variants. However, only two of these antibodies mediated complement-dependent killing although those which were ineffective were nevertheless complement-fixing antibodies. These results indicate that antibodies to closely positioned epitopes on protein I vary in their biological activities and that the conserved epitope recognized by the antibody SM 24 is potentially an effective target on the gonococcal surface for immunoprophylaxis.
\end{abstract}

\section{INTRODUCTION}

The existence of antigenic shift in expression of gonococcal surface proteins during the course of an infection poses considerable problems for vaccine development. Since adhesion of gonococci to epithelial cells of the genital tract is the first step in pathogenesis (Ward et al., 1974), an effective method of gonorrhoea control would be prevention of gonococcal attachment to host cells. However, the two surface components which have been implicated in this process, pili and outer membrane protein II (P.II) readily undergo antigenic variation (Heckels, 1986). Studies with monoclonal antipilus antibodies have revealed that while antibodies directed against variable determinants inhibit adhesion (Virji \& Heckels, 1984) and promote phagocytosis (Virji \& Heckels, 1985), antibodies directed against those conserved regions which are immunogenic do not protect in the model systems (Heckels, 1986). Thus protection against different gonococcal strains expressing variable adhesins may not be easily achieved unless a common region involved in attachment to all different epithelial cells is identified (Rothbard $e t$ al., 1985). An alternative strategy is to investigate the potential protective effect of antibodies directed against other surface structures which may be common to all gonococci.

The universal occurrence in gonococci of protein I (P.I), its abundance in the outer membrane $(\mathrm{OM})$ and its comparatively conserved nature (Britigan et al., 1985) suggest that this protein may be a good candidate for incorporation in a gonococcal vaccine. It is not subject to antigenic variation within a strain but varies between strains. However, although many P.I serotypes

\footnotetext{
Abbreviations: CL, chemiluminescence; DGI, disseminated gonococcal infection; OM, outer membrane(s); PMN, polymorphonuclear leucocytes.
} 
exist, only two major forms of the protein, type IA (P.IA) and IB (P.IB), have been described. Variant molecules within each group exhibit considerable homology but there is little shared structure between the groups (Swanson, 1979; Sandstrom et al., 1982).

A previous study has identified and located a conserved epitope in P.IB by the use of a crossreacting monoclonal antibody, SM24. This antibody did not react with P.IA-expressing strains, but it reacted equally well with all P.IB-expressing gonococci, which account for over $40 \%$ of randomly selected fresh isolates (Fletcher et al., 1986). This study reports the use of monoclonal antibody SM24 in model systems to investigate the protective effect of antibodies directed against the conserved determinant, with a view to assess its potential value as a vaccine component. In addition we have studied the biological effect of antibodies directed against the closely located type-specific epitopes and have also investigated if their competitive binding affects the biological activity of the cross-reacting antibody.

\section{METHODS}

Bacterial strains and growth conditions. Several variants of $N$. gonorrhoeae strain P9 expressing different surface proteins were used. These included variant $\mathrm{P} 9-1$, the non-piliated $\left(\mathrm{Pil}^{-}\right)$variant lacking protein II (P.II $\left.{ }^{-}\right)$in addition to a Pil ${ }^{+}$P.II- variant (P9-2) and a Pil+ P.II+ variant (P9-17) previously described (Virji \& Heckels, 1986). Several fresh clinical isolates which expressed major OM protein IB (Fletcher et al., 1986) were used after minimum subculture or after selection of particular colonial phenotypes (Lambden \& Heckels, 1979). The antigen profiles of these variants were confirmed by SDS-PAGE for the heat modifiable P.II (Lambden \& Heckels, 1979) and by dot blots using antipilus monoclonal antibody SM1 for the presence of pili (Virji \& Heckels, 1983). All gonococci were grown on clear typing medium at $37^{\circ} \mathrm{C}$ in an atmosphere of $5 \%(\mathrm{v} / \mathrm{v}) \mathrm{CO}_{2}$ for $16-20 \mathrm{~h}$ (Fletcher et al., 1986).

For biological experiments gonococci were suspended in tissue culture media (vide infra) or Dulbecco's complete phosphate-buffered saline (PBSB; Oxoid). Aggregates were removed by centrifugation at $100 \mathrm{~g}$ for $2 \mathrm{~min}$ and the concentration of gonococci in suspension was determined from the DNA released after lysis with $1 \%(\mathrm{w} / \mathrm{v})$ SDS in $0.1 \mathrm{M}-\mathrm{NaOH}$ (Virji \& Heckels, 1986).

Monoclonal antibodies. Production of the monoclonal antibodies used in these studies has been described (Fletcher et al., 1986). Ascitic fluids containing high concentrations of monoclonal antibodies (1-5 mg ml-1) were obtained by intraperitoneal growth of the cloned hybrids and were used in most experiments. Five antibodies reacting with $\mathrm{P}$.IB were used, four were type-specific, reacting with a limited number of strains expressing P.IB and one, SM24, cross-reacted with all the strains tested which expressed this protein. Antibodies SM20, SM21 and SM24 belonged to subclass IgG2a whereas SM 22 and SM23 were of isotypes IgG3 and IgM respectively (Fletcher et al., 1986). Purified Ig used in some experiments was obtained by affinity chromatography with protein ASepharose (Sigma) (Fletcher et al., 1986).

Cytotoxicity assay. Chang conjunctiva epithelial cells (Flow Laboratories) were grown in medium 199 with Earl Salts supplemented with $10 \%(\mathrm{v} / \mathrm{v})$ foetal calf serum (FCS, Gibco). For cytotoxicity assays, monolayers were prepared in 96-well plates by seeding tissue culture cells at $10^{5}$ per well in medium 199 containing $2 \%$ FCS (maintenance medium, MM) as previously described (Virji \& Everson, 1981). Gonococci were suspended in MM, enumerated and diluted to obtain a range of infective doses. To determine the protective effect of monoclonal antibodies, epithelial cell monolayers were challenged with gonococci (dose range $10^{3}$ to $10^{7} \mathrm{c.f} . \mathrm{u}$. per monolayer) and incubated for $24 \mathrm{~h}$ at $37^{\circ} \mathrm{C}$ in an atmosphere of $5 \%(\mathrm{v} / \mathrm{v}) \mathrm{CO}_{2}$ in air, either in the presence or absence of antibodies. Ascitic fluids containing anti-P.IB antibodies were decomplemented at $56^{\circ} \mathrm{C}$ for 30 min and filtersterilized before dilution in MM for use in these experiments. For control experiments ascitic fluids which had no detectable anti-gonococcal antibodies were used. After $24 \mathrm{~h}$ incubation under these conditions, viability of the epithelial cells was determined by a dye assay (Virji \& Heckels, 1984). Briefly, the target monolayers were washed and the viable cells still attached to the wells were fixed in absolute methanol before staining with safranin-O (Raymond A. Lamb, North Acton, Middlesex). Excess dye was washed off, stained cells were solubilized with $1 \%$ (w/v) SDS in $0 \cdot 1 \mathrm{M}-\mathrm{NaOH}$ and the $A_{+92}$ was measured in a Titertek Multiscan photometer (Flow Laboratories). Results presented are from one typical experiment out of at least three which were done with quadruplicate estimation of each data point.

Bactericidal killing. Individual human sera were screened by ELISA and those with the lowest reactivities with gonococcal OM antigens were used as a complement source. Bactericidal activity of the monoclonal antibodies was determined by a microtechnique described previously (Virji \& Heckels, 1985). Approximately 1500 c.f.u. of gonococci were incubated in PBSB containing $1 \%(\mathrm{v} / \mathrm{v})$ FCS in the presence of ascitic fluids containing antibodies and human serum complement. Controls with antibodies and decomplemented serum or with complement alone were always included. Survival of gonococci was determined after $1 \mathrm{~h}$ incubation at $37^{\circ} \mathrm{C}$ by plating samples on 
solid media for the estimation of c.f.u. Each estimation was done in quadruplicate and each experiment was done at least twice. Results of one typical experiment are shown.

Preparation of human polymorphs. Polymorphonuclear leucocytes (PMN) were prepared from peripheral blood obtained from healthy volunteers with no history of gonococcal infections. For isolation of PMN, monocytepolymorph resolving medium (M-PRM, Flow Laboratories) was used (Virji \& Heckels, 1986). Approximately 18 $\mathrm{ml}$ blood was layered onto $10 \mathrm{ml} \mathrm{M}-\mathrm{PRM}$ in $22 \mathrm{~mm}$ diam. plastic universal bottles (Sterilin) and centrifuged at $300 \mathrm{~g}$ for $40 \mathrm{~min}$. The PMN band which separated from leucocytes and the erythrocyte pellet was collected, washed in PBS and suspended in RPMI-1640 medium (Flow Laboratories). The preparation contained PMN with $>97 \%$ viability as measured by trypan blue exclusion.

Opsonization by monoclonal antibodies. Luminol-enhanced chemiluminescence (CL) of PMN was used to study the relative efficacy of the monoclonal antibodies in opsonization (Virji \& Heckels, 1985). CL was recorded as c.p.m. at intervals during a 90 min incubation period in a scintillation counter (LKB MiniBeta, LKB Wallac) with ${ }^{3} \mathrm{H}$ preset windows and at ambient temperature. Scintillation vials contained $1 \mathrm{ml}$ reaction mixture comprising $4 \times 10^{5}$ PMN, $2 \times 10^{7}$ gonococci, 40 $\mu \mathrm{M}$-Luminol (Sigma) and, when present, antibody at 1:500 dilution and complement or decomplemented serum at $2 \%$ final concentration. Three preparations of PMN from different individuals produced essentially the same results.

\section{RESULTS}

\section{Protective effect of monoclonal antibodies}

Chang conjunctiva epithelial cells exhibit differences in susceptibility to the toxic effect of different gonococcal variants in a dose-dependent manner. In order to study the protective effect of anti-P.IB antibodies, host cells were challenged with several variants of gonococcal strain P9 expressing different surface antigens as well as a $\mathrm{Pil}^{+} \mathrm{P} \mathrm{II}^{+}$recent isolate. In each case the challenge dose was chosen to obtain $>70 \%$ death of the epithelial cells after $24 \mathrm{~h}$ exposure in the absence of antibodies. The cross-reacting antibody SM 24 protected the host cells considerably against the toxic effect of gonococci since, when this antibody was included in the assay, killing was always reduced to $<15 \%$ regardless of the variant present (Fig. 1). The efficacy of the typespecific antibodies was studied using one variant, P9-17, which was chosen for its phenotypic resemblance to fresh isolates (i.e. Pil ${ }^{+}$P.II ${ }^{+}$). Exposure of Chang cells to this variant caused $>90 \%$ killing at doses of $>10^{5}$ gonococcal c.f.u. per monolayer. The toxic effect was virtually abolished at the lower doses not only in the presence of the cross-reacting antibody SM24 but also equally well with the type-specific antibodies SM21, SM22 and SM23 (Fig. 2). However, antibody SM20 was ineffective at a wide range of dilutions tested. This antibody was used in further experiments to investigate if its competitive binding could inhibit protection afforded by the other antibodies. SM22 was chosen to illustrate this point since radioimmunoassays had shown the greatest (up to $50 \%$ ) inhibition of SM22 by SM20 (Fletcher et al., 1986). However, in these cytotoxicity experiments no inhibition of protection of SM22 by SM20 was observed (Table 1).

That the protection of the epithelial cells was due to the presence of antibodies in ascites was shown in control experiments which used ascites lacking any detectable anti-gonococcal antibodies. These were not protective whereas purified $\mathrm{IgG}$ from ascites containing antibody SM24 retained its protective effect.

\section{Bactericidal effect of anti-P.IB antibodies}

The ability of the cross-reacting antibody SM24 to initiate complement-mediated killing of gonococci was investigated using a panel of variants comprising three different strains: P9 and two recent isolates which were resistant to $10 \%$ fresh normal human serum. All gonococci tested were susceptible to the action of this antibody and human complement, although some variation in sensitivity was observed with the different strains (Fig. 3).

The efficacy of the type-specific antibodies was studied in similar assays using a single variant P9-17 (Fig. 4). Antibodies SM21 (isotype $\gamma 2 \mathrm{a}$ ) and SM22 $(\gamma 3)$ were bactericidal at a range of dilutions, whereas SM20 $(\gamma 2 \mathrm{a})$ and SM23 $(\mu)$ were essentially ineffective under these conditions. However, these antibodies did not block the effect of bactericidal antibodies, including the cross-reacting SM24, even when present simultaneously at 10 -fold greater concentrations. In 


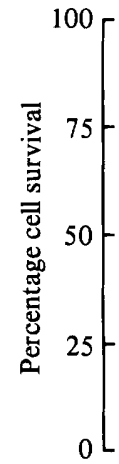

Variant...

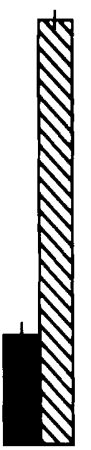

P9-1

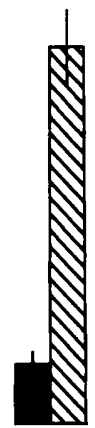

P9-2

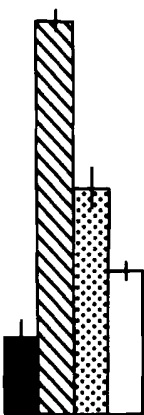

P9-17

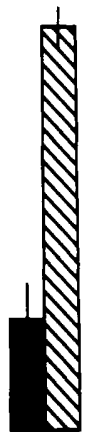

SU72 $\mathrm{Pil}^{+}$P.II ${ }^{+}$

Fig. 1. Inhibition of gonococcal virulence by antibody SM24. Chang conjunctiva epithelial cells growing in monolayers were challenged with different variants of gonococci at doses which killed $>70 \%$ of cells in control wells $(\square)$. Each well contained P9-1 $\left(2 \times 10^{5}\right.$ c.f.u. $)$, P9-2 $\left(2.3 \times 10^{4}\right.$ c.f.u. $)$, P9-17 $\left(5.6 \times 10^{3}\right.$ c.f.u. $)$ or SU72 $\left(1.9 \times 10^{5}\right.$ c.f.u. $)$. Host cell survival in the presence of antibody at a dilution of $1: 100(\$)$ was determined in each case. Effect of antibody dilution is also shown in the case of variant P9-17: $, 1: 100 ;$ 图, $1: 250 ; \square, 1: 500$. Bars denote SDs of quadruplicate estimations.

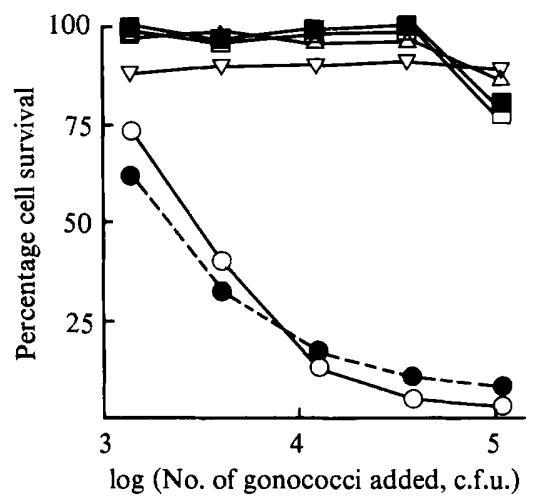

Fig. 2. Protection of Chang conjunctiva epithelial cells in the presence of anti-P.IB antibodies. Survival of the host cells was estimated after $24 \mathrm{~h}$ exposure to different numbers of gonococci (variant P9-17) in the presence of cross-reacting antibody SM24 ( $\square$ ) or type-specific antibodies SM20 (O), SM21 ( $\square$ ), SM22 $\triangle)$ or SM23 $(\nabla)$. Control incubations contained ascitic fluid which had no detectable anti-gonococcal antibodies (O). All ascitic fluids were present at a final dilution of $1: 100$. Mean values of quadruplicate estimations are shown. SDs were $< \pm 10 \%$ of host survival.

Table 1. Competition of antibodies in cytotoxicity assay

\begin{tabular}{|c|c|c|c|c|c|}
\hline \multirow[b]{2}{*}{$\begin{array}{l}\text { No. of } \\
\text { gonococci* }\end{array}$} & \multirow[b]{2}{*}{$\begin{array}{r}\text { Antibody ... } \\
\text { Dilution ... }\end{array}$} & \multicolumn{4}{|c|}{ Percentage cell survival $\dagger$} \\
\hline & & None & $\begin{array}{c}\text { SM20 } \\
1: 20\end{array}$ & $\begin{array}{l}\text { SM22 } \\
1: 100\end{array}$ & $\begin{array}{r}\text { SM } 20+\text { SM } 22 \\
1: 20+1: 100\end{array}$ \\
\hline $\begin{array}{r}1.8 \times 10^{4} \\
6 \times 10^{3}\end{array}$ & & $\begin{array}{r}7 \\
11\end{array}$ & $\begin{array}{l}5 \\
6\end{array}$ & $\begin{array}{l}97 \\
98\end{array}$ & $\begin{array}{r}95 \\
100\end{array}$ \\
\hline
\end{tabular}

* Challenge dose of gonococci per monolayer of tissue culture cells.

$\dagger$ Percentage survival of tissue culture cells was determined as described in the text. 


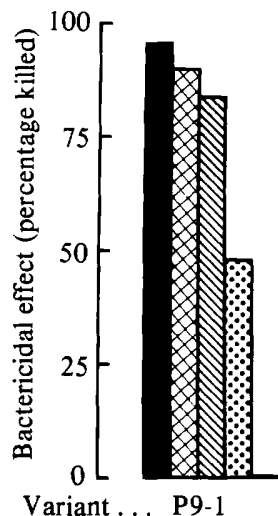

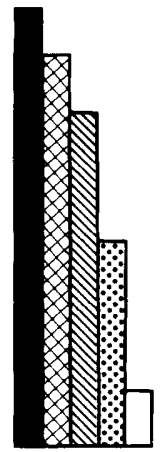

P9-2

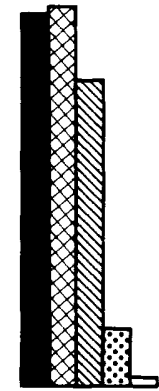

P9-17

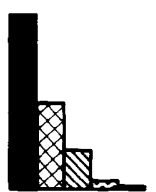

SU53

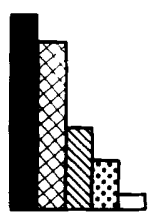

SU72

Fig. 3. Bactericidal effect of cross-reacting antibody SM24. Variants of strain P9 as well as two fresh clinical isolates were incubated with antibody SM24 (IgG2a) in the presence of $10 \%(\mathrm{w} / \mathrm{v})$ fresh human

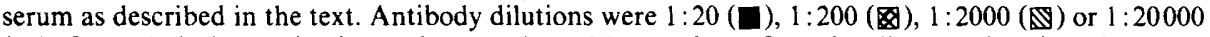
( $⿴ 囗 ⿱ 一 一)$. Controls $(\square)$ contained complement alone. Mean values of quadruplicate estimations from one typical experiment are shown. SDs were $< \pm 20 \%$.

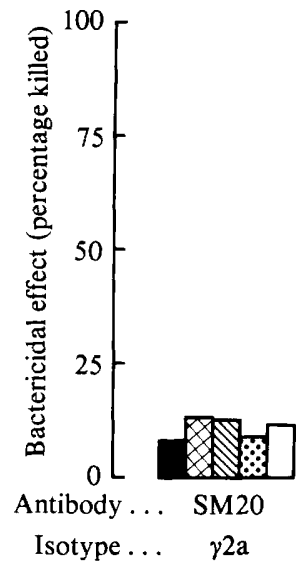

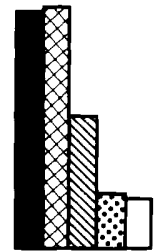

SM21

$\gamma 2 \mathrm{a}$

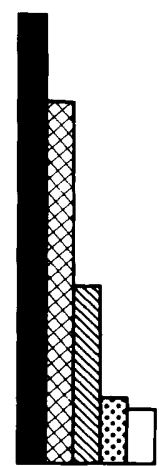

SM22

$\gamma 3$

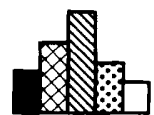

SM23

Fig. 4. Bactericidal action of type-specific monoclonal antibodies on variant P9-17. Serial 10-fold dilutions of ascitic fluid containing monoclonal antibodies were used in the presence of $10 \%(\mathrm{w} / \mathrm{v})$ fresh human serum as a source of complement. Antibody dilutions were $1: 20(\square), 1: 200(\mathbb{Q}), 1: 2000(\mathbb{N})$ or $1: 20000(\square)$. Controls $(\square)$ contained complement alone. Mean values of quadruplicate estimations from one typical experiment are shown. SDs were $< \pm 20 \%$.

further experiments SM20 and SM23 were allowed to bind to gonococci for $15 \mathrm{~min}$ at $37^{\circ} \mathrm{C}$ before addition of complement. Under these conditions both antibodies were bactericidal but only at the highest dilution of $1: 20$. Thus, under optimum conditions, all antibodies were bactericidal but exhibited varying abilities to mediate complement killing. Control experiments showed that gonococcal c.f.u. estimations were not influenced by the presence of antibodies alone.

\section{Opsonic effect of anti-P.I antibodies}

Variants of strain P9 and four recent isolates expressing P.IB were used in a CL assay in the presence of the cross-reacting antibody SM24. In each case, the presence of the antibody increased gonococcal interactions with PMN, which resulted in enhanced CL. Since the presence of P.II increases gonococcal interactions with human PMN in the absence of opsonins (Virji \& Heckels, 1986), the influence of variation in expression of these antigens and of pili was 

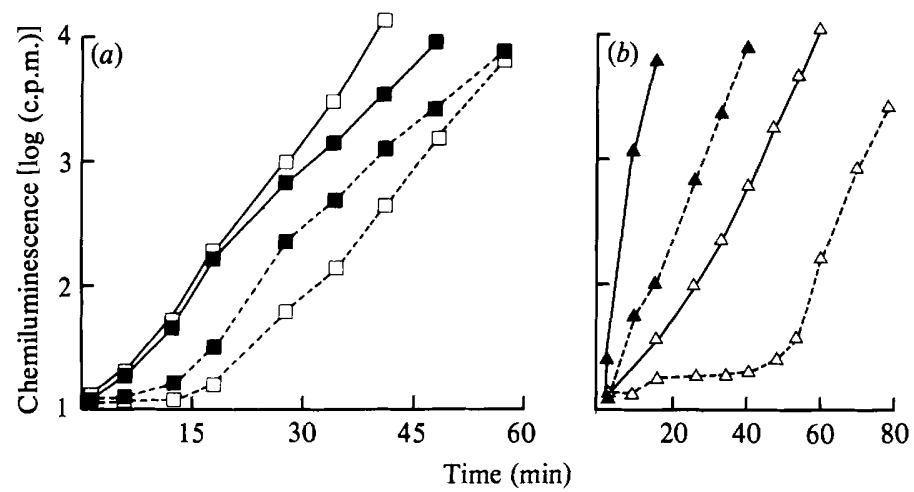

Fig. 5. Opsonization of gonococcal variants by cross-reacting anti-P.I antibody. Variants from two P.IB-expressing gonococcal strains were used in a CL assay in the presence of human PMN. Luminolenhanced $\mathrm{CL}$ was recorded as c.p.m. at regular intervals in a scintillation counter. Gonococci and PMN were present at a ratio of $50: 1$ either with (-) or without (--) the cross-reacting antibody SM24. (a) Strain SU72: $\square, \mathrm{Pil}^{+}$P.II ${ }^{+}$isolate expressing two P.II $\left(M_{\mathrm{r}} 32000\right.$ and 28000); $\square$, Pil $^{-}$P.II ${ }^{+}$variant SU72-3 expressing a single P.II $\left(M_{\mathrm{r}} 32000\right)$. (b) Strain SU50: $\Delta, \mathrm{Pil}^{+} \mathrm{P} . \mathrm{II}^{+}$isolate expressing two P.II $\left(M_{\mathrm{r}} 29000\right.$ and 28000$) ; \triangle, \mathrm{Pil}^{+}$P.II- variant SU50-1.

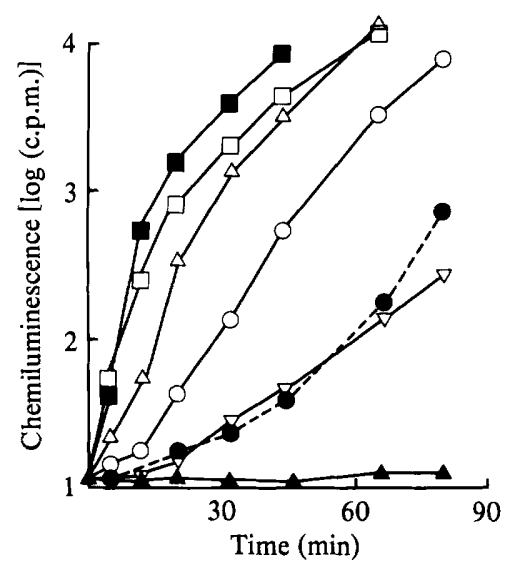

Fig. 6. Opsonization of a P.II- variant with type-specific and cross-reacting antibodies. Variant P9-2 was incubated with human PMN at a ratio of $50: 1$. CL induced by P9-2 was recorded with or without anti-P.IB antibodies. IgG antibodies present at 1:500 dilution were type-specific SM20 (O), SM21 $(\square)$, SM22 $\triangle$ ) and cross-reacting SM24 ( $\square)$. Controls included PMN and gonococci in the absence of antibody ( $)$, in the presence of type-specific $\operatorname{IgM}$ antibody SM23 $(\nabla)$ and PMN alone $(\mathbf{\Delta})$.

studied. For this purpose, colonial variants of two recent isolates (SU50, SU72) were selected after subculture on agar. These included $\mathrm{P} \mathrm{II}^{-}$and $\mathrm{Pil}^{-}$variants. A total of 12 variants from strains SU50 and SU72 expressing different P.II and pili were opsonized effectively with SM24. Examples of variants from these strains are illustrated in Fig. 5. All variants of strain P9 studied were similarly opsonized by SM24. Fig. 6 illustrates this for one variant, P9-2. This Pil- P.IIvariant of strain P9 was chosen for further studies with the type-specific antibodies since it induced the lowest level of CL in the absence of opsonins. All type-specific antibodies of IgG class were opsonic (Fig. 6). In each case, antibodies SM21, SM22 and SM24 were marginally more effective than SM20. All antibodies including SM23 of class IgM induced a further increase in $\mathrm{CL}$ when fresh human serum complement was present at $2 \%$ (Table 2). Identical observations were made with $\mathrm{Pil}^{+}$P.II ${ }^{+}$variant P9-17. 
Table 2. Effect of complement on opsonization of variant P9-2 by anti-P.IB antibodies

Relative CL is expressed as a ratio of c.p.m. after $20 \mathrm{~min}$ incubation of P9-2 and PMN in the presence of antibody compared with c.p.m. in the absence of antibody. Complement $(+)$ or decomplemented serum (-) were present throughout.

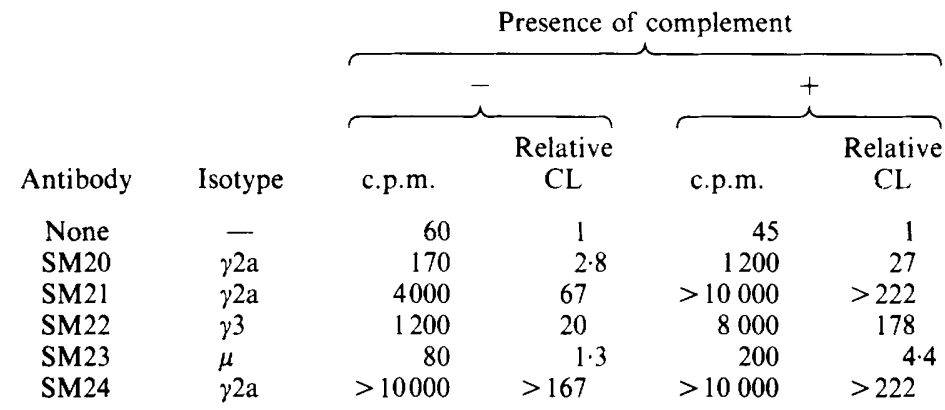

\section{DISCUSSION}

Gonococcal virulence is primarily determined by the ability of bacteria to attach to and invade epithelial tissues. The roles of pili and P.II in attachment of the bacteria are well documented (Punsalang \& Sawyer, 1973; Mårdh \& Weström, 1976; McGee et al., 1983; Lambden et al., 1979). However, as yet unknown factors enable the organism to enter host cells where they multiply and disseminate to subepithelial tissues (Ward et al., 1974). Whether the outcome of initial invasion is a localized, uncomplicated disease or a disseminated gonococcal infection (DGI) depends on the ability of the bacteria to evade host defences. Complementmediated bactericidal killing plays an important role in the control of dissemination, as shown by the observation that DGI strains tend to be resistant to the bactericidal action of normal human serum (Schoolnik et al., 1976; Brooks et al., 1976) and that patients deficient in lytic complement components tend to be more prone to such infections (Petersen et al., 1976; Lee et al., 1978). In addition, cellular phagocytic immune mechanisms may also play a role in the control of the disease. PMN associated with gonococci are abundant in urethral exudates of patients, suggesting the importance of these interactions (Veale et al., 1979). The association of gonococci with polymorphs is increased by the expression of P.II and organisms which shift to the P.II- phenotype resist phagocytic killing (Virji \& Heckels, 1986). In the latter case opsonic antibodies must play an important role in influencing gonococcal-PMN interactions and hence the subsequent course of the infection. Thus the disease that is manifested reflects the success of the organism at overcoming successive interactions with the host. Consequently, the efficacy of a vaccine may depend on evoking antibodies which interfere with gonococci at various stages of infection. In evaluating P.I as a possible vaccine candidate we have used three model systems, which include a cytotoxicity assay to study epithelial cell invasion, in vitro complement-mediated killing and polymorph $\mathrm{CL}$ as a measure of PMN-gonococcal interactions. We have used a panel of monoclonal antibodies reacting with P.IB (Fletcher et al., 1986) in these assays to assess their possible protective value during the course of gonococcal infection.

The cytotoxicity assay, using Chang epithelial cells in tissue culture, mimics gonococcal infection of vaginal epithelial cells since infection in both cases involves endocytosis of the organism (Watt et al., 1976; Heckels \& Virji, 1986). In this model system, the antibody SM24, which recognizes a conserved P.IB epitope, reduced virulence of two gonococcal strains which were tested. Similarly, three type-specific antibodies were protective against the variant P9-17. One antibody, SM20, was an exception, even though it was of high avidity (Fletcher $e t$ al., 1986) and clearly bound whole gonococci, as was evident from opsonization studies discussed below. These observations emphasize the importance of the precise location of epitopes on P.IB in protection by antibodies directed to them. Further investigations showed that antibody SM20 did not reduce the protective effect of SM22, although it competed with this antibody in competitive binding assays and caused up to $50 \%$ inhibition of binding of labelled SM 22 
(Fletcher et al., 1986), indicating that effective protection may be obtained even in the absence of saturation binding by protective antibodies. The precise mechanism of protection is not yet known but it is unlikely to result from simple bacterial agglutination, since we have previously shown a lack of protection with agglutinating antisera (Virji, 1981), suggesting that other mechanisms must operate. Blake \& Gotschlich (1983) have suggested that P.I may actively participate in the virulence mechanisms of gonococci by insertion into host cell membranes thus possibly supplying electrical signalling mechanisms which result in the endocytosis of the organism. If such a mechanism exists, then antibodies to P.I may prevent this process by blocking sites of contact of P.I with host cell membrane thus inhibiting uptake.

Other biological assays also revealed protective effects of anti-P.IB antibodies with the crossreacting SM24 performing a universally effective role. In the presence of complement, SM24 was bactericidal for several gonococcal strains although some variation in the extent of killing of different strains was apparent. Such differences have been reported even within variants of the same strain (McCutchan et al., 1976; Lambden et al., 1979), however, the reasons for such varying susceptibilities are not entirely clear. Thus while varying in degree, SM24 was nevertheless significantly bactericidal for all strains tested. Under optimal conditions, all typespecific antibodies were also bactericidal but exhibited a wide range in their abilities to bring about complement damage. The least effective antibodies were of isotypes $\gamma 2 \mathrm{a}$ (SM20) and $\mu$ (SM23), which were nevertheless able to bind complement, as was also revealed indirectly by opsonization studies. However, the reason for their reduced bactericidal efficiency may be due to quantitative differences in complement fixation by the monoclonal antibodies or indeed due to the location or orientation of their epitopes (Joiner et al., 1985; Virji \& Heckels, 1985).

In contrast to the above systems, all antibodies were effective in opsonization as measured by a PMN CL increase. Previous studies have shown that the CL increase is paralleled by phagocytic killing of gonococci (Virji \& Heckels, 1985). The IgG class antibodies were opsonic alone. This effect was increased by the presence of complement which, in addition, produced opsonization with the IgM antibody (SM23). Thus all the P.IB antibodies are potentially effective in mediating phagocytic killing. Previous studies have shown that antipilus antibodies are opsonic (Jones et al., 1980; Virji \& Heckels, 1985) and have suggested incorporation of pili in vaccines in order to raise opsonic antibodies (Jones et al., 1980). However, the opsonic antipilus antibodies are of limited value since they tend to be type-specific (Jones et al., 1980; Virji \& Heckels, 1985). The current studies show that P.IB may be of greater value since antibodies directed against its conserved epitope are opsonic.

From the current study antibodies to P.IB appear to be effective at three levels. Mucosal immunity can prevent initial invasion of epithelial cells and, in addition, both complementmediated bactericidal and phagocytic host defences can be activated by these antibodies. Further, studies with different variants have revealed that even the P.II- variants, which are most likely to cause DGI because of their resistance to phagocytosis (Virji \& Heckels, 1986), are opsonized by the anti-P.I antibodies. Bactericidal antibodies may be of particular importance in prevention of salpingitis since Buchanan et al. (1980) have reported that anti-P.I antibodies may be involved in serotype-specific protection against gonococcal salpingitis.

The most significant observation from these studies is that one cross-reacting monoclonal antibody is effective in all three protective mechanisms studied. Since the antibody recognizes over $40 \%$ of clinical isolates, it would appear that the conserved peptide antigen of P.IB may be a good candidate for a multicomponent vaccine, which would necessarily also include a common component of P.IA. However, the role of cross-reacting antibodies against P.IA awaits investigation.

This work was supported by an MRC Project Grant.

\section{REFERENCES}

Blake, M. S. \& GotsChlich, E. C. (1983). Gonococcal membrane proteins: speculation on their role in pathogenesis. Progress in Allergy 33, 298-313.

Britigan, B. E., Cohen, M. S. \& Sparling, P. F.
(1985). Gonococcal infection: a model of molecular pathogenesis. New England Journal of Medicine 312, 1683-1694.

Brooks, G. F., Israel, K. S. \& Petersen, B. H. (1976). 
Bactericidal and opsonic activity against Neisseria gonorrhoeae in sera from patients with disseminated gonococcal infection. Journal of Infectious Diseases 134, 450-462.

Buchanan, T. M., EschenbaCh, D. A., KnapP, J. S. \& Holmes, K. K. (1980). Gonococcal salpingitis is less likely to recur with Neisseria gonorrhoeae of the same principal outer membrane protein antigenic type. American Journal of Obstetrics and Gynecology 138 , 978-980.

Fletcher, J. N., ZaK, K., VirJi, M. \& Heckels, J. E. (1986). Monoclonal antibodies to gonococcal outer membrane protein $\mathrm{I}$ : location of a conserved epitope on protein IB. Journal of General Microbiology 132 , $1611-1620$.

Heckels, J. E. (1986). Gonococcal antigenic variation and pathogenesis. In Antigenic Variation in the Course of Infectious Diseases: a Survival Strategy for Pathogenic Microorganisms. Edited by H. Birkbeck \& C. W. Penn. Cambridge: Cambridge University Press (in the Press).

HeCKels, J. E. \& VIRJI, M. (1986). Antigenic variation of gonococcal surface proteins: effect on virulence. In Molecular Biology of Microbial Pathogenicity. Edited by S. Normark. London: Academic Press (in the Press).

JoIner, K. A., Warren, K. A., TAM, M. \& Frank, M. M. (1985). Monoclonal antibodies directed against gonococcal protein I vary in bactericidal activity. Journal of Immunology 134, 3411-3419.

Jones, R. B., Newland, J. C., Olsen, D. A. \& Buchanan, T. M. (1980). Immune-enhanced phagocytosis of Neisseria gonorrhoeae by macrophages: characterisation of the major antigens to which opsonins are directed. Journal of General Microbiology 121, 365-372.

Lambden, P. R. \& Heckels, J. E. (1979). Outer membrane protein composition and colonial morphology of Neisseria gonorrhoeae strain P9. FEMS Microbiology Letters 5, 263-265.

LAMBden, P. R., Heckels, J. E., James, L. T. \& WATT, P. J. (1979). Variations in surface protein composition associated with virulence properties in opacity types of Neisseria gonorrhoeae. Journal of General Microbiology 114, 305-312.

Lee, T. J., Schmoyer, A., Snyderman, R., Yount, W. J. \& Sparling, P. F. (1978). Familial deficiencies of the sixth and seventh components of complement associated with bacteremic Neisseria infections. In Immunobiology of Neisseria gonorrhoeae, pp. 204-206. Edited by G. F. Brooks, E. C. Gotschlich, K. K Holmes, W. D. Sawyer \& F. E. Young. Washington, DC: American Society for Microbiology.

McCutchan, J. A., Levine, S. \& Braude, A. I. (1976). Influence of colony type on susceptibility of gonococci to killing by human serum. Journal of Immuno$\log y$ 116, 1652-1655.

McGee, Z. A., Stephens, D. S., Hoffman, L. H., SCHLECH, W. F., III \& HORN, R. G. (1983). Mechanisms of mucosal invasion by pathogenic Neisseria. Reviews of Infectious Diseases 5, S708S714.

MÅRDH, P. A. \& WESTRÖM, L. (1976). Adherence of bacteria to vaginal epithelial cells. Infection and Immunity 13, 661-666.
Petersen, B. H., Graham, J. A. \& Brooks, G. F. (1976). Human deficiency of the eighth component of complement. The requirement of $\mathrm{C} 8$ for serum Neisseria gonorrhoeae bactericidal activity. Journal of Clinical Investigation 57, 283-290.

Punsalang, A. P. \& Sawyer, W. D. (1973). Role of pili in the virulence of Neisseria gonorrhoeae. Infection and Immunity 8, 255-263.

Rothbard, J. B., Fernandez, R., Wang, L., Teng, N. N. H. \& SchoolNIK, G. K. (1985). Antibodies to peptides corresponding to a conserved sequence of gonococcal pilins block bacterial adhesion. Proceedings of the National Academy of Sciences of the United States of America 82, 915-919.

Sandstrom, E. G., Chen, K. C. S. \& Buchanan, T. M. (1982). Serology of Neisseria gonorrhoeae: coagglutination serogroups WI and WII/III correspond to different outer membrane protein molecules. Infection and Immunity 38, 462-470.

SCHOOLNIK, G. K., Buchanan, T. M. \& Holmes, K. K. (1976). Gonococci causing disseminated gonococcal infection are resistant to the bactericidal action of normal human sera. Journal of Clinical Investigation 58, 1163-1173.

SWANSON, J. (1979). Studies on gonococcus infection. XVIII. "125I-labelled peptide mapping of the major protein of the gonococcal cell wall outer membrane. Infection and Immunity 23, 799-810.

Veale, D. R., Goldner, M., PenN, C. W., Ward, J. \& SMITH, H. (1979). The intracellular survival and growth of gonococci in human phagocytes. Journal of General Microbiology 113, 383-393.

VIRJI, M. (1981). The effect of antibody directed against outer membrane antigens on the virulence of a pilated variant of Neisseria gonorrhoeae. FEMS Microbiology Letters 12, 355-358.

VIRJI, M. \& Everson, J. S. (1981). Comparative virulence of opacity variants of Neisseria gonorrhoeae strain P9. Infection and Immunity 31, 965-970.

VIRJ, M. \& HeCKELS, J. E. (1983). Antigenic crossreactivity of Neisseria pili: investigations with typeand species-specific monoclonal antibodies. Journal of General Microbiology 129, 2761-2768.

VIRJI, M. \& HECKELS, J. E. (1984). The role of common and type-specific pilus antigenic domains in adhesion and virulence of gonococci for human epithelial cells. Journal of General Microbiology 130, 10891095.

VIRJI, M. \& HeCKeLS, J. E. (1985). Role of anti-pilus antibodies in host defense against gonococcal infection studied with monoclonal anti-pilus antibodies. Infection and Immunity 49, 621-628.

VIRJI, M. \& HeCKELS, J. E. (1986). The effect of protein II and pili on the interaction of Neisseria gonorrhoeae with human polymorphonuclear leucocytes. Journal of General Microbiology 132, 503-512.

WARD, M. E., WATt, P. J. \& Robertson, J. N. (1974). The human fallopian tube: a laboratory model for gonococcal infection. Journal of Infectious Diseases 129, 650-659.

Watt, P. J., Ward, M. E. \& Robertson, J. N. (1976). The interaction of gonococci with host cells. In Sexually Transmitted Diseases, pp. 89-101. Edited by D. Catterall \& K. Nicol. London: Academic Press. 